\title{
Impression cytologic analysis after corneal cross-linking and insertion of corneal ring segments for keratoconus: two-year results
}

\author{
Citologia de impressão após "cross-linking" corneano e inserção dos segmentos de \\ anéis corneanos para ceratocone: dois anos de seguimento
}

Adimara da Candelaria Renesto ${ }^{1}$, Jeison de Nadai Barros ${ }^{2}$, Mauro Campos $^{1}$

\begin{abstract}
Purpose: To report the impression cytologic results after corneal cross-linking and insertion of intrastromal corneal ring segments for keratoconus.

Methods: Thirty-nine eyes were distributed into two groups: 1) cross-linking group (patients underwent corneal cross-linking procedure), and 2) riboflavin eyedrops group (patients received $0.1 \%$ riboflavin ( $\mathrm{w} / \mathrm{v}$ ) eyedrops in $20 \%$ dextran solution for 1 month) After 3 months, all patients underwent insertion of intrastromal corneal ring segments. Impression cytologic specimens were obtained from all eyes at baseline, at 1 month and 3 months after cross-linking or riboflavin eyedrops, and again at 6 months, 1 year, and 2 years after intrastromal corneal ring segment insertion.

Results: Patients in the cross-linking group demonstrated improvement in the cellto-cell contact of epithelial cells and the nucleus-to-cytoplasm ratio on the temporal conjunctiva after treatment $(P=0.008$ and $P=0.047)$, respectively. On the superior conjunctiva, increases in goblet cell density ( $\mathrm{P}=0.037)$ and level of organization of nuclear chromatin $(P=0.010)$ after treatment were noted. Patients in the riboflavin eyedrops group demonstrated improvement in the cell-to-cell contact of epithelial cells on the superior conjunctiva after treatment $(P=0.021)$. On the temporal conjunctiva, an improvement in the cell-to-cell contact of epithelial cells $(\mathrm{P}<0.001)$ and increases in the nucleus-to-cytoplasm ratio $(P<0.001)$, goblet cell density $(P=0.001)$, and less keratinization ( $P=0.011)$ were noted. No changes were identified on the cornea for either group. Fisher's exact test comparison of the impression cytologic total scores after treatment revealed no difference between groups.
\end{abstract}

Conclusion: Despitechanges in some conjunctival parameters (e.g., cell-to-cell contac of epithelial cells, nucleus-to-cytoplasm ratio, level of organization of nuclear chromatin goblet cell density, and keratinization), comparison of the total impression cytologic scores revealed no difference between groups.

Keywords: Cytological techniques; Cornea; Riboflavin; Keratoconus; Corneal surgery, laser; Corneal stroma

\section{RESUMO}

Objetivo: Relataros resultados de citologia de impressão após o "cross-linking" da córnea e inserção dos segmentos de anéis corneanos intraestromais para ceratocone.

Métodos: Trinta e nove olhos foram distribuídos em dois grupos: pacientes no grupo cross-linking foram submetidos ao procedimento do "cross-linking" corneano e pacientes no grupo colírio de riboflavina receberam o colírio de riboflavina 0,1\% (W/V)-20\% dextran para uso tópico por um mês. Após três meses, todos os pacientes foram submetidos à inserção dos segmentos de anéis corneanos intraestromais. Citologia de impressão foi realizada em todos os olhos no pré-operatório, um mês e três meses após o "cross-linking" ou colírio de riboflavina, enovamente com seis meses, um ano e dois anos após a inserção dos segmentos de anéis.

Resultados: Pacientes do grupo "cross-linking" apresentaram melhora na adesividade das células epiteliais e proporção núcleo: citoplasma na conjuntiva temporal após o tratamento $(P=0,008$ e $P=0,047)$, respectivamente. Naconjuntiva superior, houve um aumentona densidade das células caliciformes $(P=0,037)$ e nível de organização da cromatina nuclear $(P=0,010)$ apóso tratamento. Pacientes do grupo colírio deriboflavinaapresentarammelhora na adesividade das células epiteliais na conjuntiva superior após o tratamento $(P=0,021)$. Na conjuntiva temporal, houve melhora na adesividade das células epiteliais ( $P<0,001)$, aumentonaproporçãonúcleo: citoplasma $(P<0,001)$, células caliciformes $(P=0,001)$ emenor queratinização $(P=0,011)$. Ambos os grupos não apresentaram alterações corneanas. $O$ Teste exato de Fisher para comparação de citologia de impressão no escore total após o tratamento não revelou diferença entre os grupos.

Conclusão: Apesar de mudanças em alguns parâmetros conjuntivais (adesividade das células epiteliais, proporção núcleo:citoplasma, nível de organização da cromatina nuclear, células caliciformes e queratinização), a comparação do escore total na citologia de impressão não apresentou diferença entre os grupos.

Descritores: Técnicas citológicas; Córnea; Riboflavina; Ceratocone; Cirurgia da córnea a laser; Substância própria

\section{INTRODUCTION}

Keratoconus is a noninflammatory cone-like ectasia of the cornea that can be managed by glasses, contact lenses, keratoplasty, cross-linking $(C X L)^{(1)}$, and intrastromal corneal ring segment (ICRS) ${ }^{(2-3)}$ insertion, based on the stage of the disease and the patient's symptoms. Despite being an evolutive disease, CXL has recently been utilized as a therapeutic option for stabilizing the cornea(1)

An optical microscopic study ${ }^{(4)}$ demonstrated that the morphology grade of the most superficial epithelial cells obtained by impression cytology (IC) from the cornea and bulbar conjunctiva did not change after CXL using riboflavin and ultraviolet-A (UVA) light in the treatment of keratoconus.

Some patients have been pretreated with CXL, and ICRS can be performed in conjunction to the produce, flattening the central corneal curvature, which decreases corneal irregularity and improves visual acuity ${ }^{(5)}$. To the authors' knowledge, no report on the cytological features of the ocular surface epithelium after CXL and ICRS insertion in the treatment of keratoconus currently exists in the literature.

The aim of this study was to report the IC features of the conjunctiva and cornea after CXL and ICRS insertion in the treatment of keratoco-
Submitted for publication: May 10, 2011

Accepted for publication: December 23, 2011

Study carried out at Department of Ophthalmology, Universidade Federal de São Paulo - UNIFESP.

${ }^{1}$ Physician, Department of Ophthalmology, Refractive Surgery Service, Universidade Federal de São Paulo - UNIFESP - São Paulo (SP), Brazil.

Certified Ophthalmic Medical Technologist of Visual Science, Department of Ophthalmology, Universidade Federal de São Paulo - UNIFESP - São Paulo (SP), Brazil.
Funding: No specific financial support was available for this study

Disclosure of potential conflicts of interest: A.C.Renesto, None; J.N.Barros, None; M.Campos, None. Projeto № 1915/07; Comitê de Ética em Pesquisa da Universidade Federal de São Paulo/Escola Paulista de Medicina. Este ensaio clínico tem seu registro em: clinicaltrials.gov (NCT00832897) Correspondence address: Adimara da Candelaria Renesto. Rua Botucatu, 821 - 2 andar - São Paulo (SP) - 04023-062 - Brazil - E-mail: adimararenesto@uol.com.br 
nus and to compare the results with those patients presenting with similar stages of the same disease.

\section{METHODS}

An interventional prospective randomized clinical trial was conducted between March 2008 and December 2010 at the Vision Institute, Department of Ophthalmology, Federal University of São Paulo, São Paulo, Brazil. This study was approved by the Institutional Ethics Committee and conducted according to the tenets of the Declaration of Helsinki. All patients provided informed consent.

Patients diagnosed with documented keratoconus with a corneal thickness of at least $400 \mu \mathrm{m}$ and a history of intolerance to contact lens fitting were recruited for the study. Exclusion criteria included previous ocular surgery; only one functional eye; corneal opacity on the axis; corneal curvature $>65$ diopters; history of herpetic keratitis; moderate dry eye; autoimmune disease; and pregnancy. The criteria for the diagnosis of dry eye included tear film, punctacte keratitis, and patient complaint.

A total of 39 eyes of 31 patients were included. All eyes were graded according to the Amsler-Krumeich classification ${ }^{(6)}$, based on patient's refraction, mean central K-reading, corneal signs, and corneal thickness. All treated eyes were graded stage II or III. Using a randomized table, patients were distributed into two study groups according to the treatment: CXL group (19 eyes underwent CXL procedure using riboflavin and UVA light) and riboflavin eyedrops (RE) group (20 eyes received $0.1 \%$ riboflavin (wt/vol) eyedrops $[10 \mathrm{mg}$ riboflavin-5-phosphate in 20\% (wt/vol) dextran-T-500; Ophthalmos, São Paulo, Brazil] 4 times per day for 1 month.

In eight patients, both eyes were included. In these eight cases, the right eye received only $R E$, and the left eye underwent the $C X L$ procedure. After 3 months of this first step (CXL or RE), all patients then underwent insertion of ICRS (Keraring, Mediphacos, Belo Horizonte, Brazil), which comprised the second step.

Clinical data collected included patients' demographic features (e.g., age, race, and gender). All patients underwent routine ophthalmologic evaluation (uncorrected distance visual acuity and corrected distance visual acuity assessment, slit-lamp biomicroscopy, Goldmann applanation tonometry, and ocular fundus examination), corneal topography (EyeSys-2000 Corneal Topography instrument; EyeSys Vision, Irvine, CA), Orbscan IIz examination (Bausch \& Lomb Gmbh, Feldkirchen, Germany), Pentacam examination (Oculus Optikgerate Gmbh, Wetzlar, Germany), Visante Optical Coherence Tomography (OCT; Carl Zeiss Meditec, Dublin, CA), and IC before treatment and at 1 month and 3 months after CXL or RE, and again at 6 months, 1 year, and 2 years after ICRS insertion.

\section{IC TECHNIQUe}

After the slit-lamp examination, all patients were subjected to IC sampling by the same researcher (A.C.R.). Following the application of topical anesthesia, IC specimens were collected (Millipore HAWP304; Bedford, MA) from the four quadrants of the cornea, from an exposed area of the bulbar conjunctiva (temporal region), and from an unexposed area of the conjunctiva (superior region) adjacent to the corneal limbus. All strips were processed for periodic acid-Schiff and Gill hematoxylin staining. Glass slides mounted with Entellan (Merck, Darmstadt, Germany) were analyzed under light microscopy by an experienced professional (J. N. B.), operating in a masked fashion. For quality control, only IC specimens with at least one-third of the filter surface covered with visible epithelial cells were included.

Conjunctival samples were evaluated according to established techniques for the following parameters ${ }^{(7-9)}$ : cellularity, cell-to-cell contact of epithelial cells, nucleus-to-cytoplasm (N:C) ratio, nuclear chromatin level, goblet cell density, keratinization, and distribution of inflammatory cells. A score of 0 to 3 was assigned to each of these features. Zero represented normal findings. One represented borderline features, and 2 or 3 represented abnormal features. The scores obtained for each parameter were added together to obtain a total score and classified as A or normal (total score 0-3), B or borderline (total score 4-6), and C or abnormal (total score $>6$ ). Goblet cell densities were judged as normal when abundant, borderline when slightly or moderately reduced, and abnormal when distinctly reduced (single to no goblet cells). Corneal samples were evaluated and graded according to the squamous metaplasia classification proposed by Murube and Rivas ${ }^{(10)}$.

\section{Cross-Linking Procedure}

The cross-linking procedure in the CXL group was performed by the same surgeon (M.C.) according to the standard protocol $\left.\right|^{(11)}$. 0.5\% proxymetacaine hydrochloride (wt/vol) eyedrops were applied. After a 9-mm diameter abrasion of the corneal epithelium, drops of a $0.1 \%$ riboflavin solution (wt/vol) in 20\% dextran were applied onto the cornea every 5 minutes for a total of 30 minutes. Using a slit lamp with a blue filter, the surgeon confirmed the presence of riboflavin in the anterior chamber before UVA irradiation commenced. The cornea was exposed (using a lid speculum) to UV light (UV-X System; Peschke Meditrade GmbH, Hunenberg, Switzerland), which emits light at a wavelength of $370 \pm 5 \mathrm{~nm}$ at an irradiance of $3 \mathrm{~mW} / \mathrm{cm}^{2}$ or $5.4 \mathrm{~J} / \mathrm{cm}^{2}$ for 30 minutes (medium spot). During this time, riboflavin solution was applied every 5 minutes. The limbus and conjunctiva were not protected during irradiation. Topical anesthetic was applied as required during the surgery.

After the treatment, a soft bandage contact lens was applied until reepithelialization was complete. A combination of $0.5 \%$ moxifloxacin (wt/vol) and $0.1 \%$ dexamethasone phosphate (wt/vol) eyedrops (Alcon Laboratories, Fort Worth, TX) was prescribed q.i.d. for 2 weeks.

\section{INTRASTROMAL CORNEAL RING SEGMENT IMPLANTATION}

Intrastromal corneal ring segment implantation was performed by one of the authors (M.C.) in an operating room under sterile conditions using topical anesthetic drops. The Purkinje reflex was chosen as the central point and marked under a biomicroscope. A 5.0-mm marker was used to locate the exact ring channel. Tunnel depth was set at $80 \%$ of the thinnest corneal thickness on the tunnel location.

The arc length and thickness were chosen according to the manufacturer's nomogram. A 60-kHz femtosecond laser (IntraLase Corp, Irvine, CA) was used to create the ring channels. The channel's inner diameter was set to $5.0 \mathrm{~mm}$, and the outer diameter was set to $5.9 \mathrm{~mm}$. The entry-cut thickness was $1 \mu \mathrm{m}$, and the ring energy for channel creation was $1.70 \mu \mathrm{J}$. The entry-cut energy was $1.10 \mu \mathrm{J}$, and channel creation timing with the femtosecond laser was 15 seconds. The ICRS was implanted immediately after channel creation and before the disappearance of the bubbles, which revealed the exact tunnel location.

Postoperatively, a combination of $0.5 \%$ moxifloxacin (wt/vol) and $0.1 \%$ dexamethasone phosphate (wt/vol) eyedrops (Alcon Laboratories) was prescribed q.i.d for 2 weeks. The patients were instructed to avoid rubbing their eyes and to use artificial tears frequently. On the first postoperative day, slit-lamp biomicroscopic examination was performed. Wound healing and segment migration were evaluated.

Follow-up IC examinations were scheduled at baseline, at 1 month and 3 months after CXL or RE, and again at 6 months, 1 year, and 2 years after ICRS insertion.

\section{Statistical analysis}

Fisher's exact test was applied to evaluate the IC grades. The Friedman test was used to compare evaluations made at baseline, at 1 month and 3 months after CXL or RE, and again at 6 months, 1 year, and 2 years after ICRS insertion. Calculations were performed using the statistical software Minitab version 15.1 (Minitab, Inc., State College, PA). The level of statistical significance was set at $P<0.05$. 


\section{RESULTS}

Of the 31 patients, 23 were women (74.19\%) and 8 were men (25.80\%). The mean ages of the patients were $28.30 \pm 9.3$ years (range, 17-55 years) in the CXL group and $30.40 \pm 9.1$ years (range, 22-55 years) in the RE group. Both groups were similar before treatment, as assessed by corneal keratometry (flattest-K1 and steepest-K2 meridian) and spherical equivalent measurements (Table 1).

Table 2 summarizes the IC results. When IC was compared between the two groups (Table 3), no significant difference was observed at any time point. According to the Friedman test, a significant difference by IC was identified when certain parameters were com- pared over time. Improvement in cell-to-cell contact of epithelial cells $(P=0.008)$ (Figure $1 \mathrm{~A})$ and in the nucleus-to-cytoplasm $(\mathrm{N}: \mathrm{C})$ ratio $(P=0.047)$ (Figure $1 B)$ on the temporal conjunctiva in the $C X L$ group was noted. On the superior conjunctiva, increases in goblet cell density $(P=0.037)$ (Figure $2 A)$ and level of organization of nuclear chromatin $(\mathrm{P}=0.010)$ (Figure $2 \mathrm{~B}$ ) after treatment were observed. In the RE group, improvement in cell-to-cell contact of epithelial cells on the superior conjunctiva ( $\mathrm{P}=0.021$ ) (Figure 3 ) after treatment was noted. On the temporal conjunctiva, an improvement in cell-to-cell contact of epithelial cells $(P<0.001)$ (Figure $4 \mathrm{~A})$, and increases in the $\mathrm{N}: C$ ratio $(P<0.001)$ (Figure $4 \mathrm{~B})$, goblet cell density $(P=0.001)$ (Figure

Table 1. Topographic results (D) and spherical equivalent (D)

\begin{tabular}{lcccccccc}
\hline Group & Measure & N & Mean & SD & Minimum & Median & Maximum & P \\
\hline CXL & K1 & 19 & 48.10 & 4.21 & 41.41 & 47.50 & 55.87 & 0.197 \\
RE & K1 & 20 & 46.50 & 3.39 & 41.66 & 46.29 & 54.87 \\
CXL & K2 & 19 & 53.26 & 5.11 & 43.10 & 52.98 & 61.25 \\
RE & K2 & 20 & 52.17 & 3.89 & 45.06 & 51.09 & 63.92 \\
CXL & SE & 19 & -7.41 & 3.48 & -14.00 & -6.50 & -1.75 \\
RE & SE & 20 & -5.45 & 3.53 & -13.50 & -4.50 & 0.054 \\
\hline
\end{tabular}

$\mathrm{D}=$ diopters; $\mathrm{N}=$ number of eyes; $\mathrm{P}=$ significance level $(\mathrm{t}$ test); $\mathrm{SD}=$ standard deviation; $\mathrm{CXL}=$ cross-linking group; $\mathrm{RE}=$ riboflavin eyedrops group; $\mathrm{SE}=$ spherical equivalent; $\mathrm{K} 1=$ minimum keratometry; $\mathrm{K} 2=$ maximum keratometry

Table 2. Impression cytologic (IC)

\begin{tabular}{|c|c|c|c|c|c|c|c|c|c|c|c|}
\hline & $\begin{array}{c}A \\
N(\%)\end{array}$ & $\begin{array}{c}B \\
N(\%)\end{array}$ & $\begin{array}{c}C \\
N(\%)\end{array}$ & & $\begin{array}{c}A \\
N(\%) \\
\end{array}$ & $\begin{array}{c}\text { B } \\
N(\%) \\
\end{array}$ & $\begin{array}{c}\mathrm{C} \\
\mathrm{N}(\%) \\
\end{array}$ & & $\begin{array}{c}A \\
\mathrm{~N}(\%) \\
\end{array}$ & $\begin{array}{c}\text { B } \\
\mathrm{N}(\%)\end{array}$ & $\begin{array}{c}C \\
N(\%)\end{array}$ \\
\hline $\begin{array}{l}\text { Total score } \\
\text { corneal class }\end{array}$ & & & & $\begin{array}{l}\text { Total score } \\
\text { superior class }\end{array}$ & & $\begin{array}{c}P * \\
C X L=0.251 \\
R E=0.042\end{array}$ & & $\begin{array}{l}\text { Total score } \\
\text { temporal class }\end{array}$ & & $\begin{array}{c}P^{*} \\
C X L=0.359 \\
R E=0.018\end{array}$ & \\
\hline $\begin{array}{l}\text { Pretreatment } \\
\mathrm{CXL} \\
\mathrm{RE}\end{array}$ & $\begin{array}{l}19(100.0) \\
20(100.0)\end{array}$ & - & - & $\begin{array}{l}\text { Pretreatment } \\
\mathrm{CXL} \\
\mathrm{RE}\end{array}$ & $\begin{array}{l}17(94.4) \\
16(80.0)\end{array}$ & $\begin{array}{l}1(5.6) \\
3(15.0)\end{array}$ & $1(5.0)$ & $\begin{array}{l}\text { Pretreatment } \\
\mathrm{CXL} \\
\mathrm{RE}\end{array}$ & $\begin{array}{l}11(64.7) \\
12(60.0)\end{array}$ & $\begin{array}{l}5(29.4) \\
6(30.0)\end{array}$ & $\begin{array}{l}1(5.9) \\
2(10.0)\end{array}$ \\
\hline $\begin{array}{l}1 \text { month } \\
C X L \\
\text { RE }\end{array}$ & $\begin{array}{l}19(100.0) \\
20(100.0)\end{array}$ & - & - & $\begin{array}{l}1 \text { month } \\
C X L \\
\text { RE }\end{array}$ & $\begin{array}{l}15(78.9) \\
18(94.7)\end{array}$ & $\begin{array}{l}4(21.1) \\
1(5.3)\end{array}$ & - & $\begin{array}{l}1 \text { month } \\
C X L \\
\text { RE }\end{array}$ & $\begin{array}{l}14(73.7) \\
12(63.2)\end{array}$ & $\begin{array}{l}5(26.3) \\
6(31.6)\end{array}$ & $1(5.3)$ \\
\hline $\begin{array}{l}3 \text { months } \\
\text { CXL } \\
\text { RE }\end{array}$ & $\begin{array}{l}18(100.0) \\
20(100.0)\end{array}$ & - & - & $\begin{array}{l}3 \text { months } \\
C X L \\
\text { RE }\end{array}$ & $\begin{array}{l}12(70.6) \\
17(94.4)\end{array}$ & $\begin{array}{l}5(29.4) \\
1(5.6)\end{array}$ & - & $\begin{array}{l}3 \text { months } \\
C X L \\
\text { RE }\end{array}$ & $\begin{array}{l}14(87.5) \\
16(84.2)\end{array}$ & $\begin{array}{l}1(6.3) \\
3(15.8)\end{array}$ & $\begin{array}{c}1(6.3) \\
-\end{array}$ \\
\hline $\begin{array}{l}6 \text { months } \\
C X L \\
\text { RE }\end{array}$ & $\begin{array}{l}16(94.1) \\
19(100.0)\end{array}$ & $\begin{array}{c}1(5.9) \\
-\end{array}$ & - & $\begin{array}{l}6 \text { months } \\
\mathrm{CXL} \\
\mathrm{RE}\end{array}$ & $\begin{array}{l}16(94.1) \\
17(100.0)\end{array}$ & $1\left(\begin{array}{l}5.9) \\
-\end{array}\right.$ & - & $\begin{array}{l}6 \text { months } \\
\mathrm{CXL} \\
\mathrm{RE}\end{array}$ & $\begin{array}{l}15(93.8) \\
15(88.2)\end{array}$ & $\begin{array}{l}1(6.3) \\
2(11.8)\end{array}$ & - \\
\hline $\begin{array}{l}1 \text { year } \\
C X L \\
\text { RE }\end{array}$ & $\begin{array}{l}18(100.0) \\
19(100.0)\end{array}$ & - & - & $\begin{array}{l}1 \text { year } \\
C X L \\
\text { RE }\end{array}$ & $\begin{array}{l}18(100.0) \\
19(100.0)\end{array}$ & - & - & $\begin{array}{l}1 \text { year } \\
C X L \\
\text { RE }\end{array}$ & $\begin{array}{l}15(88.2) \\
17(94.4)\end{array}$ & $\begin{array}{l}2(11.8) \\
1(5.6)\end{array}$ & - \\
\hline $\begin{array}{l}2 \text { years } \\
C X L \\
R E\end{array}$ & $\begin{array}{l}15 \text { ( 93.8) } \\
19(100.0)\end{array}$ & $\begin{array}{c}1(6.3) \\
-\end{array}$ & - & $\begin{array}{l}2 \text { years } \\
C X L \\
R E\end{array}$ & $\begin{array}{l}17(100.0) \\
18(90.0)\end{array}$ & $1(5.0)$ & $\begin{array}{c}- \\
1(5.0)\end{array}$ & $\begin{array}{l}2 \text { years } \\
C X L \\
R E\end{array}$ & $\begin{array}{l}17(100.0) \\
19(95.0)\end{array}$ & $1(5.0)$ & - \\
\hline
\end{tabular}

$\mathrm{N}=$ number of eyes; $\mathrm{CXL}=$ cross-linking group; $\mathrm{RE}=$ riboflavin eyedrops group; $\mathrm{P}^{*}=$ Friedman test was used to compare $\mathrm{IC}$ results before treatment, 1,3 , and 6 months, and at 1 and 2 years

Table 3. Fisher's exact test to compare conjunctival total scores between the two groups

\begin{tabular}{lcccccc}
\hline \multicolumn{7}{l}{ Table 3. Fisher's exact test to compare conjunctival total scores between the two groups } \\
\cline { 2 - 7 } Region & Pre-treatment & $\mathbf{1}$ month & $\mathbf{3}$ months & $\mathbf{6}$ months & $\mathbf{1}$ year & $\mathbf{2}$ years \\
\hline Superior & 0.174 & 0.147 & 0.069 & 0.500 & - & 0.285 \\
Temporal & 0.255 & 0.216 & 0.109 & 0.399 & 0.374 & 0.541 \\
\hline
\end{tabular}



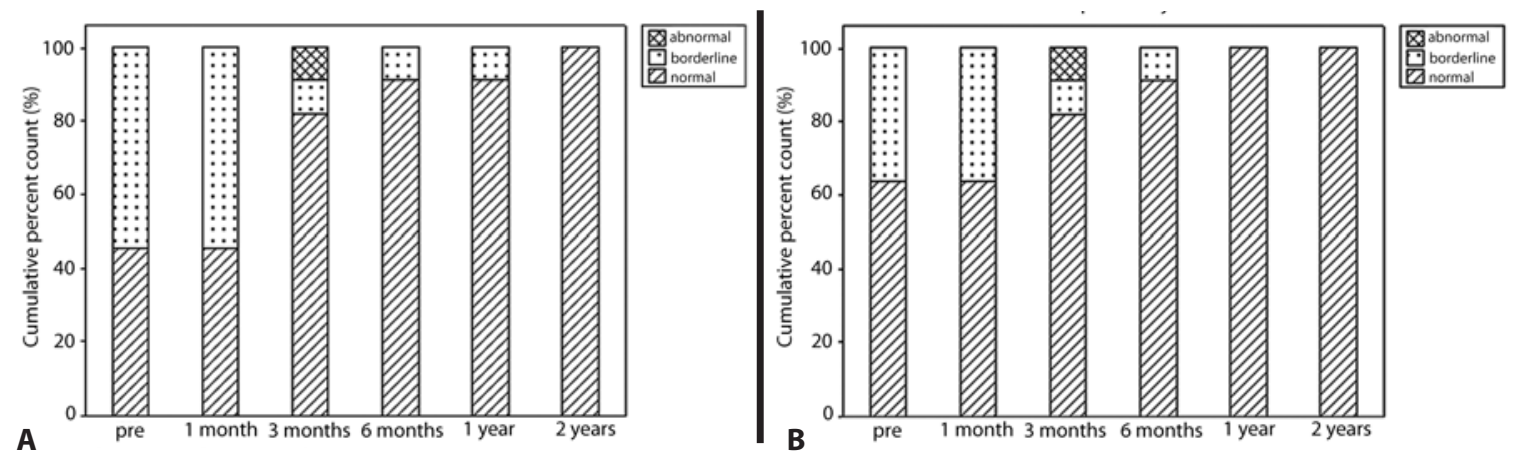

Figure 1. A) Cross-linking group: cell-to-cell contact of epithelial cells - temporal conjunctiva. B) Cross-linking group: nucleus-to-cytoplasm ratio - temporal conjunctiva.
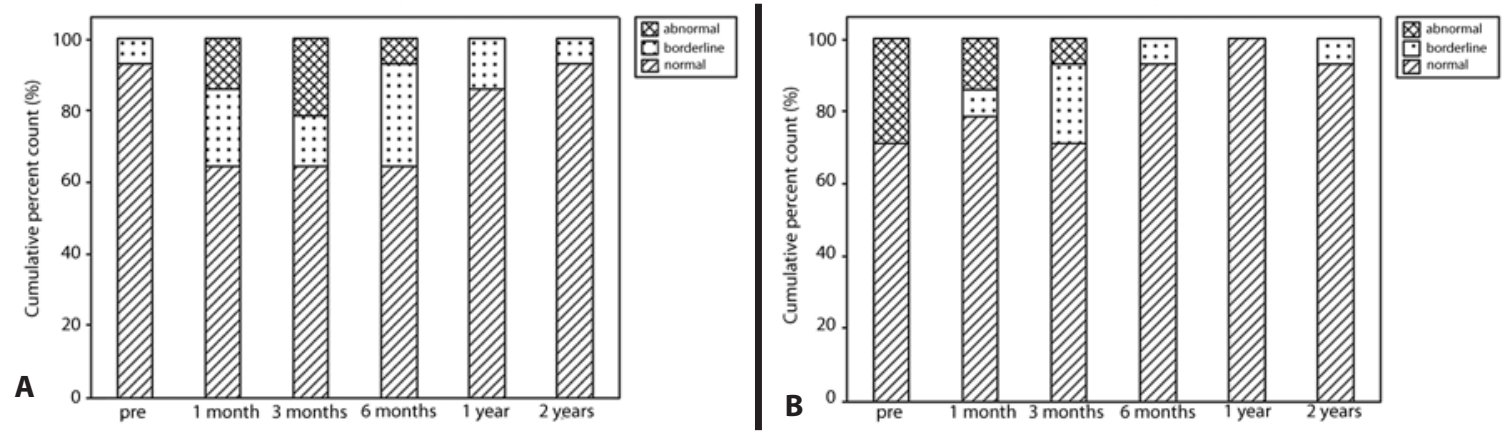

Figure 2. A) Cross-linking group: goblet cell density - superior conjunctiva. B) Cross-linking group: nuclear chromatin level - superior conjunctiva.

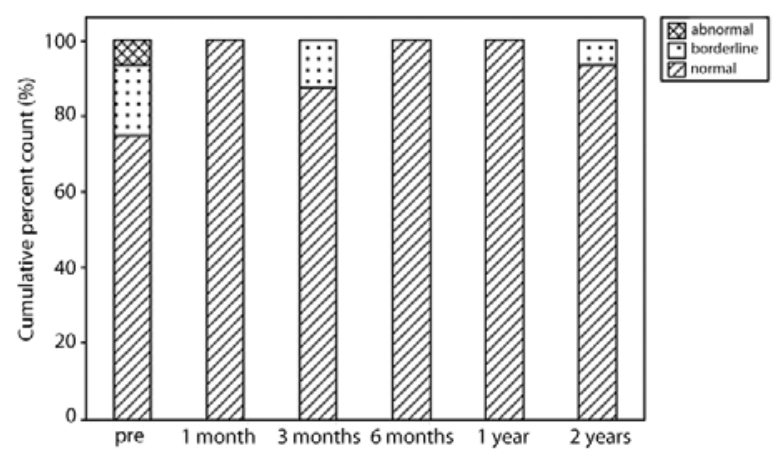

Figure 3. Riboflavin eyedrops group: cell-to-cell contact of epithelial cells superior conjunctiva.

$4 C$ ), and less keratinization ( $P=0.011)$ (Figure 4D) were observed. In both groups, the IC corneal features remained stable with a completely normal presentation both before treatment and at all follow-up times.

\section{DISCUSSION}

In the present study, the ocular surface of two groups of patients who underwent ICRS insertion was evaluated by IC. The IC technique studies the most superficial layers of cells from the corneal and conjunctival surfaces ${ }^{(12)}$. Morphological changes in the bulbar conjunctiva do not always occur in typical combinations. Therefore, a grading system (IC score) that included several morphological parameters (IC subscores) was devised to provide a complete analysis of conjunctival alteration. The parameters were separately judged and totaled to yield the final score, as described elsewhere ${ }^{(8-9)}$.
Recently, an optical microscopic study ${ }^{(4)}$ by our group demonstrated that despite changes in goblet cell density after corneal CXL in the superior conjunctiva and an improvement in the morphology of epithelial cells after the use of RE, the morphology grade of the most superficial epithelial cells obtained by IC from the cornea and bulbar conjunctiva did not change after CXL using riboflavin and UVA light in the treatment of keratoconus. This finding suggests that the CXL is a safe procedure at the 3 -month follow-up. The ICRS had not been inserted at this time point.

Now, new results from a 2-year follow-up period showed improvements in the cell-to-cell contact of epithelial cells and the $\mathrm{N}: \mathrm{C}$ ratio on the temporal conjunctiva in the CXL group. On the superior conjunctiva, an increase in the values of nuclear chromatin and goblet cells were observed at the 2-year follow-up. The conjunctival goblet cell count and the epithelial cell morphology are objective measures of the ocular surface status. The goblet cells are responsible for the production of gel-forming mucin, MUC5AC, whereas corneal and conjunctival epithelial cells synthesize transmembrane mucins, such as MUC1, 2, and 4. The gel-forming mucin constitutes the main component of the mucus layer (innermost component of the film) ${ }^{(13)}$, and it stabilizes the tear film.

In a previous study ${ }^{(4)}$, a reduction in goblet cell density on the superior conjunctiva was observed after the CXL. The follow-up period was only 3 months, and the authors related this finding to factors such as the toxicity of the topical medication and inflammation or mechanical damage from the lid speculum. In the present study, the effect of the CXL procedure on the cells layer from the cornea was not present anymore. The durability of the stiffening effect of the CXL is unknown; however, the collagen turnover in the cornea is estimated between 2 to 3 years ${ }^{(1)}$. Previous reports using IC have shown a greater reduction in goblet cells after femtosecond laser treatment than after mechanical microkeratomy in LASIK procedures due to the length of time that the suction ring exerts pressure on the con- 


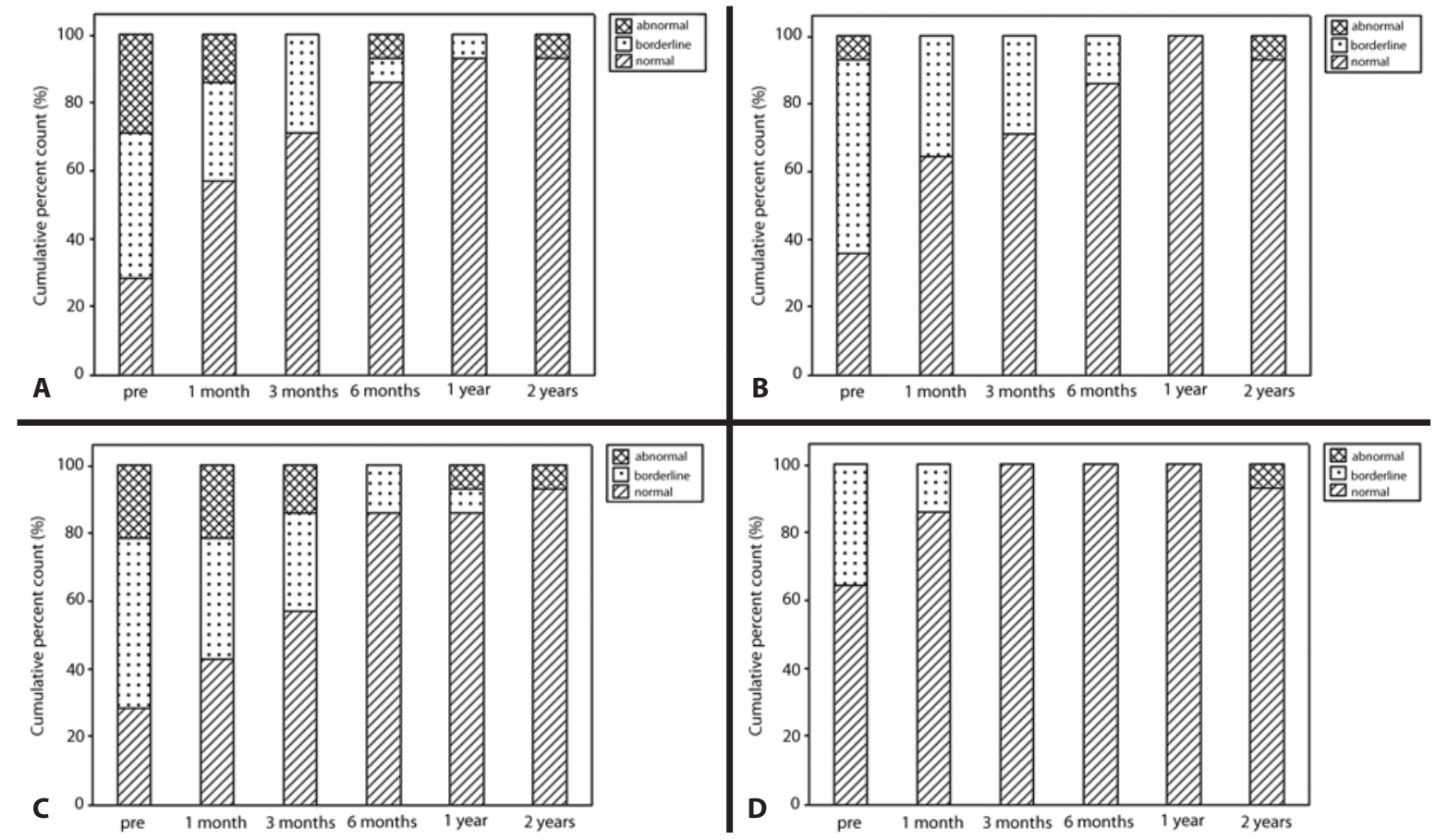

Figure 4. A) Riboflavin eyedrops group: cell-to-cell contact of epithelial cells - temporal conjunctiva. B) Riboflavin eyedrops group: nucleus-to-cytoplasm ratio - temporal conjunctiva. C) Riboflavin eyedrops group: goblet cell density - temporal conjunctiva. D) Riboflavin eyedrops group: keratinization - temporal conjunctiva.

junctiva. The destruction of corneal tissue by LASIK procedures may also directly or indirectly affect the population of goblet cells. These findings were observed at the 3-month follow-up. After 6 months, the goblet cells recovered ${ }^{(14)}$, which was similar to our experience. In our study, the femtosecond laser was used to create the channel ring at a depth of $80 \%$ of the thinnest corneal thickness on the tunnel location. Thus, the creation of the channel ring by the femtosecond laser did not affect the goblet cell density on the ocular surface in our group of patients.

In the present study, the $\mathrm{IC}$ results before and after treatment were normal (grade 0) in all corneal specimens. Although epithelial debridement before corneal CXL can cause necrosis and apoptosis ${ }^{(15)}$ of keratocytes at a depth of 50 to $60 \mu \mathrm{m}$, any significant cytotoxic effect of CXL seems to be concentrated in the anterior part of the cornea because of the high absorption of UVA light by riboflavin. This behavior prevents the light from penetrating to deeper levels and preserves the endothelium and lens. Previous reports showed neither clinically evident side effects of CXL treatment nor persistent epithelial defects ${ }^{(16)}$, with the exception of transient corneal edema and a foreign body sensation for 24-48 hours, in combination with burning and tearing that are common in photorefractive surgery. Mazzotta et al. ${ }^{(16)}$ used confocal microscopy to demonstrate that the cytotoxic effects of $C X L$, although significant, were concentrated in the first $350 \mu \mathrm{m}$ of the stroma and did not affect the adjacent structures.

In the riboflavin eyedrops group, an improvement in the cell-tocell contact of epithelial cells on superior conjunctiva was noted at the 2-year follow-up. On the temporal conjunctiva, improvements in the cell-to-cell contact of epithelial cells and keratinization, and increases in the $\mathrm{N}: \mathrm{C}$ ratio and goblet cell density were noted. Our patients used riboflavin eyedrops for 1 month, and the aforementioned parameters improved up to the 2-year follow-up. These findings are possibly related to the more regular use of artificial tears prescribed throughout the 2-year follow-up period. These patients were followed closely and encouraged to regularly use the artificial tears. Squamous metaplasia scores may have improved in the conjunctiva because of a rise in ocular surface humidity related to the regular use of artificial tears over time

Riboflavin alone produced no cell damage, which is not surprising because riboflavin is also present in the retina, liver, and heart as an essential element in normal nutrition ${ }^{(17)}$. In a previous experimental study, riboflavin played a role in the development and maintenance of the surface structures of epithelial cells ${ }^{(18)}$.

\section{CONCLUSION}

Cross-linking and intrastromal corneal ring segment insertion did not change the ocular surface morphology grade in keratoconic eyes as assessed by impression cytologic analysis.

\section{REFERENCES}

1. Wollensak G, Spoerl E, Seiler T. Riboflavin/ultraviolet-A-induced collagen crosslinking for the treatment of keratoconus. Am J Ophthalmol. 2003;135(5):620-7.

2. Tan BU, Purcell TL, Torres LF, Schanzlin DJ. New surgical approaches to the management of keratoconus and post-lasik ectasia. Trans Am Ophthalmol Soc. 2006:104: 212-20.

3. Miranda D, Sartori M, Francesconi C, Allemann N, Ferrara P, Campos M. Ferrara intrastromal corneal ring segments for severe keratoconus. J Refract Surg. 2003:19(6): 645-53.

4. Renesto AC, Barros JN, Campos M. Impression cytologic analysis after corneal collagen cross-linking using riboflavin and ultraviolet-A light in the treatment of keratoconus. Cornea. 2010:29(10):1139-44.

5. Torquetti $L$, Berbel RF, Ferrara P. Long-term follow-up of intrastromal corneal ring segments in keratoconus. J Cataract Refract Surg. 2009;35(10):1768-73.

6. Krumeich JH, Daniel J, Knülle A. Live-epikeratophakia for keratoconus. J Cataract Refract Surg. 1998;24(4):456-63.

7. Pinheiro MN Jr, dos Santos PM, dos Santos RC, Barros J de N, Passos LF, Cardoso Neto J. [Oral flaxseed oil (Linum usitatissimum) in the treatment for dry-eye Sjögren's syndrome patients]. Arq Bras Oftalmol. 2007;70(4):649-55. Portuguese.

8. Fenga C, Aragona P, Cacciola A, Ferreri F, Spatari G, Stilo A, et al. Ocular discomfort and conjunctival alterations in operating room workers. A single-institution pilot study. Int Arch Occup Environ Health. 2001;74(2):123-8.

9. de Almeida SF, de Sousa LB, Vieira LA, Chiamollera MI, Barros JN. Clinic-cytologic study of conjunctivochalasis and its relation to thyroid autoimmune diseases. Cornea. 2006;25(7):789-93. 
10. Murube J, Rivas L. Impression cytology on conjunctiva and cornea in dry eye patients establishes a correlation between squamous metaplasia and dry eye clinical severity. Eur J Ophthalmol. 2003;13(2):115-27.

11. Spoerl E, Mrochen M, Sliney D, Trokel S, Seiler T. Safety of UVA-riboflavin cross-linking of the cornea. Cornea. 2007;26(4):385-89. Comment in: J Refract Surg. 2012;28(2):91-2.

12. Gadkari SS, Adrianwala SD, Prayag AS, Khilnani P, Mehta NJ, Shaha NA. Conjunctival impression cytology - a study of normal conjunctiva. J Postgrad Med. 1992:38(1):21-3, 22A-22B.

13. Watanabe H. Significance of mucin on the ocular surface. Cornea. 2002;21(1):S17-22.

14. Rodriguez AE, Rodriguez-Prats JL, Hamdi IM, Galal A, Awadalla M, Alio JL. Comparison of goblet cell density after femtosecond laser and mechanical microkeratome in LASIK. Invest Ophthalmol Vis Sci. 2007;48(6):2570-5.
15. Wollensak G, Spoerl E, Wilsch M, Seiler T. Keratocyte apoptosis after corneal collagen cross-linking using riboflavin/UVA treatment. Cornea. 2003;23(1):43-9.

16. Mazzotta C, Balestrazzi A, Traversi C, Baiocchi S, Caporossi T, Tommasi C, et al. Treatment of progressive keratoconus by riboflavin-UVA-induced cross-linking of corneal collagen: ultrastructural analysis by Heidelberg Retinal Tomography II in vivo confocal microscopy in humans. Cornea. 2007;26(4):390-7.

17. Wollensak G, Spoerl E, Reber F, SeilerT. Keratocyte cytotoxicity of riboflavin/UVA-treatment in vitro. Eye (Lond). 2004;18(7):718-22

18. Takami Y, Gong H, Amemiya T. Riboflavin deficiency induces ocular surface damage. Ophthalmic Res. 2004:36(5):156-65. Erratum in: Ophthalmic Res. 2004 36(5):299-302.

\title{
$59^{a}$ Jornada Científica do Centro Brasileiro de Estrabismo
}

\author{
28 de julho de 2012 \\ Instituto de Ensino e Pesquisa do \\ Hospital Sírio-Libanês (IEP) \\ São Paulo (SP)
}

Informações: Email: cbe@cbo.com.br 